Environmental Politics

Vol. 21, No. 3, May 2012, 510-515

\title{
Switzerland's Green Liberal Party: a new party model for the environment?
}

\author{
Andreas Ladner* \\ IDHEAP, University of Lausanne, Switzerland

\section{A new green party enters the political landscape}

Gains in the 2007 Swiss national elections started leading members of the Green Party thinking seriously about securing a seat in the seven-member national government (Federal Council).1 Strong performances in subsequent cantonal elections fostered their aspirations, and after the Fukushima catastrophe in March 2011, most observers were confident that the Green Party would do well in the 2011 national elections and the claim for Green representation in the national government would become irresistible. 2

However, in the three cantonal elections following Fukushima, the Green Party scored rather modestly.3 Only in the Ticino (where they gained 3.5\%) did the results match their expectations. The modest increases in the other cantons were largely due to the success of Green Liberal Party (GLP), which competed for the first time in Basel-Landschaft and Luzern, achieving $4.5 \%$ and $5.9 \%$ of the votes respectively. In Zurich, where the GLP had already competed in the 2007 elections, it increased its share by $4.5 \%$ to $10.3 \%$, almost matching the Green Party (10.6\%).

It was therefore no great surprise that the GLP was among the 'winners' in the national elections on 23 October 2011, increasing its share of the vote from $1.4 \%$ to $5.4 \%$, quite an impressive improvement by Swiss standards. More surprisingly, the Green Party's vote fell $1.4 \%$ to $8.4 \%$, too low to justify a seat in the national government.4

What is the story behind this shift of ecological sympathies to the newly founded GLP? Is it the re-emergence of an old conflict or a promising new development that might benefit the environment? I examine these questions first by briefly reviewing the evolution of the Green Party over the last 30 years before examining the profiles of GLP voters and election candidates to assess what they stand for and what role the GLP might play in the future.

*Email: andreas.ladner@idheap.unil.ch 


\section{It all started with cucumbers and watermelons}

Green parties started to emerge in Switzerland in the 1970s and early 1980s, firstly - not surprisingly for a federalist country - on cantonal and local levels. Influenced by the regional characteristics and the political backgrounds of early activists, in addition to their environmental concerns the green parties represented a broad political spectrum: some, 'cucumber greens' (green both inside and outside), wanted to concentrate only on ecological matters and declined to be aligned on the traditional left-right scale; others, 'water melon- greens' had pasts in left-wing parties or alternative and new social movements (Ladner 1989, p. 156).

Given their political differences the various cantonal party groups organised themselves prior to the 1983 national elections into two distinct national parties: the cucumber-like Federation of the Green Parties in Switzerland (Fo"deration der Gru nen Parteien der Schweiz) and the water- melon-like Swiss Green Alternatives (Gru ne Alternative Schweiz). Both parties performed poorly in the election, scoring $1.9 \%$ and $1 \%$ of the vote respectively (see Figure 1).

Four years later, after several stronger election results mainly in Zurich, Berne and Geneva, their vote shares of $4.9 \%$ and $2.4 \%$ failed again to meet the high expectations fostered by the impact on public ecological awareness of acid rain and Chernobyl. Nevertheless, the Federation of the Green Parties, which had changed its name to the Swiss Green Party (Gru ne Partei der Schweiz) in 1986, gained enough seats to form a parliamentary group, which guaranteed financial resources and greater political influence.

Figure 1. The Green parties and the Social Democrats (percentage of votes in elections to the national council).Source:

http://www.bfs.admin.ch/bfs/portal/de/index/themen/17/22/publ.html?publication ID1/44585 [Accessed 23 December 2011].

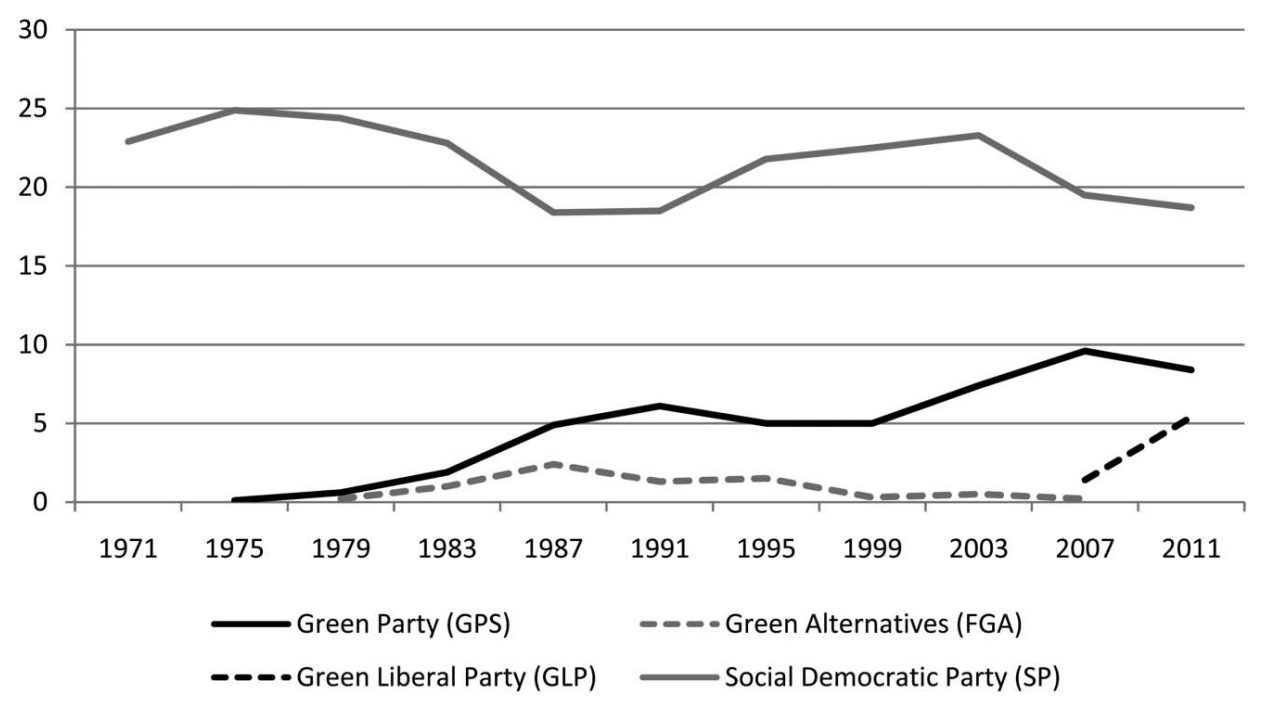


In 1991 the Swiss Green Party again increased its share of the vote to $6.1 \%$, which remained its best result until 2003. The party presented a much broader political programme, extending beyond ecological matters to include gender equality, fiscal policy, security, social and European policy (Seitz 2008, p. 24). The Green Alternatives collapsed and, with just one seat, disappeared from federal politics, leaving the Swiss Green Party as the only national-level ecological force.

\section{The Green Party's turn to the left in the 1990s}

From the late 1980s onwards the remnants of the Green Alternative became integrated in the Green Party or moved closer to it by being granted observer status in the national party organisation. By the 2007 national elections, all important Green Alternative parties in the various cantons and their leading representatives had become members of the Swiss Green Party, which in 1993 was renamed the Greens - the Green Party of Switzerland (Gru ne - Grüne Partei der Schweiz).

This process of integration and the expansion of its political focus to non- environmental issues clearly shifted the Greens leftwards (Ladner and Bra"ndle 2008, p. 123). This change was reflected in its national political activities and in the way the party perceived itself. In 1990 the presidents of the local Green party groups gave their national party a score of 3.7 on a left-right scale ranging from 1 to 10 ; in 2003, they gave it 2.5 , which was further to the left than the Social Democratic Party (see Ladner 2007, p. 322). This shift did not, however, harm their electoral progress.

\section{A second spring at the beginning of the new millennium}

As a united force the Greens again achieved electoral success in the late 1990s, starting in French-speaking areas where by 2001 the party was scoring positively in many cantonal elections. The reasons for its success included the Swiss economic recovery, increasing criticisms of globalisation, the wars in Iraq and Afghanistan, together with growing environmental problems, and perhaps the growing discontent of citizens with the performance of the four biggest parties struggling over the distribution of seats in the national government.

For its twentieth birthday in 2003 the Greens improved its result in the national elections from 5\% to $7.4 \%$, and in 2007 its $9.8 \%$ share was its highest ever. This success brought the party almost within reach of the smallest party in the seven-member government, the Christian Democrats, which, with $14.5 \%$, held one seat. Moreover, the Greens argued that it was impossible for the Liberal Party, with $15.8 \%$ of the vote, to justify its two seats in government when the Greens - with almost 10\% - was unrepresented. Thus the Greens had good reason to hope that a further increase in the 2011 elections would secure a seat in federal government. 


\section{The emergence of the Green Liberal Party}

The GLP also started out at the cantonal level. In 2004, two leading exponents of the Greens in Zurich, Verena Diener, a member of the cantonal government, and Martin Ba" umle, a member of the National Council, left their party. As reasons for their resignation they gave the increasing leftist and union orientation of the party, and organisational concerns. In the same year, they founded the Green Liberal Party of Zurich (Gru nliberale $\mathrm{Zu}$ irich).

In the 2006 elections in Zurich the GLP performed modestly, but in the 2007 cantonal elections, it achieved a very promising 5.8\%, gaining 10 seats in the 200 member cantonal parliament. A national Green Liberal Party was founded in summer 2007. Although party activities were initiated in five cantons, organisational development proceeded slowly. In that year's national election the party competed in only two cantons, securing $7 \%$ in Zurich and 3.2\% in St. Gallen. In subsequent years, the party steadily increased its presence nationwide so that by the 2011 national elections it had competed in 11 cantonal elections, gaining between $2 \%$ and $10.3 \%$ of the vote. 5

In the 2011 national elections the GLP was one of the big winners with 5.4\%. Although the Greens slipped to $8.4 \%$, together the green forces won $13.8 \%$ - more than the Christian Democrats on 12.3\%. Environmental issues apart, there are, however, no signs of closer collaboration between the two green parties; the GLP has formed an independent parliamentary group and will choose its allies on an issue-by-issue basis.

\section{Greens and Green Liberals: differences and points in common}

What are the differences between the two green parties and what do they have in common? It is not easy to position the GLP, which does not yet have a political programme. It is likely that some voters supported it simply because they did not want to vote for any other party or because it was something new.

The first post-electoral survey revealed that the GLP received votes from both sides of the political spectrum, from former supporters of the Liberal Party, the Social Democrats and the Greens.6 The mean position of GLP voters was between the Social Democrats and the Liberals, but slightly on the left of the political spectrum.

The candidates of the various parties running for the Swiss national parliament have quite distinct profiles.7 Figure 2 shows the average position of the candidates of the Social Democratic, Green, Green Liberal and Liberal parties on eight different policy dimensions. 8 There is little disagreement between Social Democrats, Greens and Liberal Greens as far as environmental matters are concerned and they, together with the Liberal Party, are also quite similar in their attitudes towards a more liberal society. A clear difference exists between the Greens and the Social Democrats on the one side, and the Green Liberals and the Liberal Party on the other with respect to the extension of the 
welfare state. Regarding the liberalisation of the economy, restrictive financial

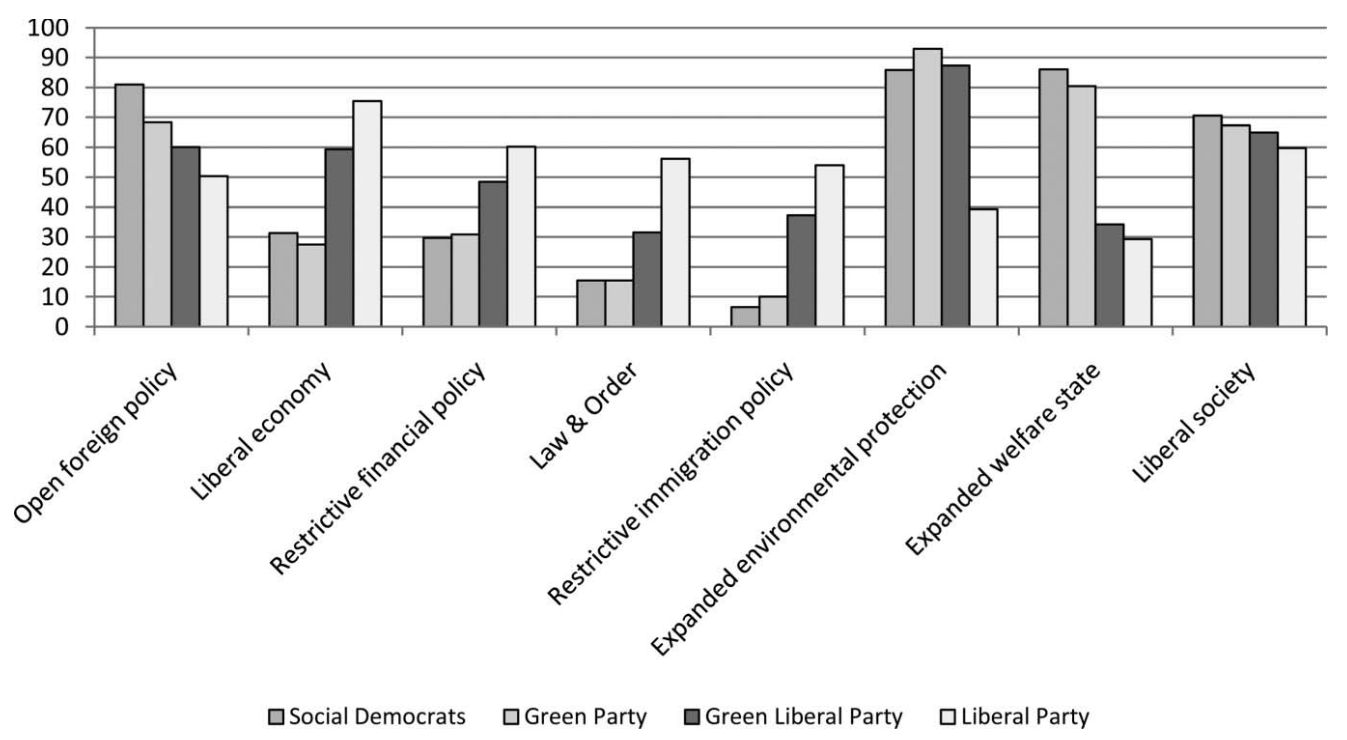

Figure 2. The positioning of Swiss parties' candidates on eight policy dimensions.

and immigrations policies, and law and order, the Green Liberals are located somewhere between the Liberals and Social Democrats/Greens. On support for a more open foreign policy there are gradual differences when moving from the Social Democrats across to the Liberal Party.

Overall, the GLP is as green as the Greens and quite liberal as far as individual liberties are concerned, but it is significantly less left-wing than the Greens. Although the GLP does not yet have a written party programme, its candidates are, like Greens candidates, quite homogenous in their policy positions; not as homogenous as the Social Democrats, but much more so than the Liberals and the Christian Democrats.

\section{The outlook for the Green Liberal Party}

Almost 30 years after the formation of the green parties at national level there is a reappearance of a more liberal, non-watermelon, Green Party in Swiss politics.

Historically, the larger Swiss parties have quickly integrated new parties by at least partly adapting their political profiles. But the considerable differences between the very leftwing Social Democrats and the GLP indicate that it is unlikely that the Social Democrats will be able to absorb the green liberal forces. The Greens, which has almost the same political profile as the Social Democrats, will also be unable to incorporate the GLP without moving to the centre, but that would require it to free itself from its left-wing and alternative heritage. On the other side of the political spectrum, there is even less danger; the Liberal Party is far too heterogeneous to move in any direction without fearing severe losses whilst the Christian Democrats are no threat as they now have a very weak presence in those places where the GLP is strong. 
The future of the GLP thus appears quite bright, although there is still a long way to go, especially when it comes to installing party organisations across the country and securing electoral sustainability. It will also be interesting to see with which parties the GLP will line up to build majorities on specific issues. Given its political profile, which distinguishes it clearly from other Swiss parties and seems to be particularly attractive in urban areas, the GLP might become an important player in Swiss politics and a role model for a new type of environmental party elsewhere.

\section{Notes}

1. The Swiss government is elected by the national parliament. It consists of seven representatives from the most important parties.

2. Although there are no formal rules allocating the seats to the parties, it is generally accepted that a party scoring well above $10 \%$ of the votes should be represented in government.

3. Basel-Landschaft p 1.6\% (27 March), Zurich p 0.1\% (3 April) and Lucerne p 1.6\% (10 April).

4. Among other 'losers' in the elections were the Swiss People's Party (SVP) 72.3\%, the Liberal Party (FDP, DieLiberalen) $72.6 \%$, the Social Democrats (SP) $70.3 \%$ and the Christian Democrats (CVP) $72.2 \%$.

5. At the end of 2011 the GLP held 53 seats (2\%) of all 2608 cantonal parliamentary seats. This is quite a promising start for such a young party that is represented in less than half the 26 cantonal parliaments. The Green Party, having won its first cantonal seat in the late 1970s, held 201 seats $(7.7 \%)$ in 21 cantonal parliaments.

6.http://www.gfsbern.ch/Neuigkeiten/tabid/177/itemid/762/amid/1151/wahltagsbefrag ung.aspx [Accessed 9 December 2011].

7. The Swiss VAA (Voting Advice Application) smartvote, allows us to analyse the political issue preferences of more than $80 \%$ of the 3500 candidates contesting the national parliament.

8. The dimensions are based on more than 70 questions on political issues. For the construction of these dimensions see http://www.smartvote.ch/downloads/methodo logy_smartspider_de_CH.pdf [Accessed 23 December 2011].

\section{References}

Ladner, A., 1989. Green and alternative parties in Switzerland. In: F. Mu"ller-Rommel, ed. New politics in Western Europe: the rise and success of green parties and alternative lists. London: Westview Press, 155-165.

Ladner, A., 2007. Political parties. In: U. Klo"ti et al., eds. Handbook of Swiss politics. 2nd ed. Zürich: Neue Zu" rcher Zeitung Publishing, 309-334. 
Ladner, A. and Bra ndle, M., 2008. Switzerland: the Green Party, Alternative and Liberal Greens. In: E.G. Frankland, P. Lucardie and B. Rihoux, eds. Green parties in transition: the end of grassroots democracy. Aldershot: Ashgate, 109-128.

Seitz, W., 2008. 'Melonengru“ne' und 'Gurkengru“ne'. In: W. Seitz and M. Baer, eds. Die Grünen in der Schweiz: Ihre Politik, ihre Geschichte, ihre Basis. Zurich: Ru“egger Verlag, 39_ 54. 